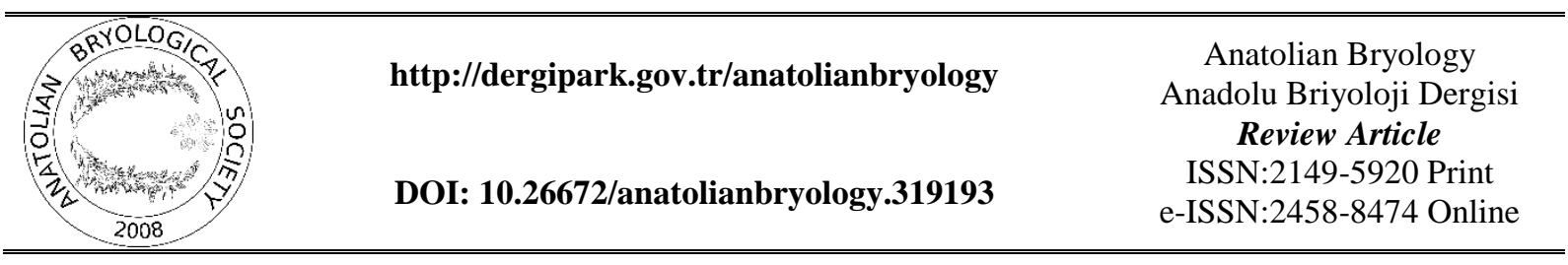

\title{
A preliminary list of subalpine and alpine bryophytes of Rize, North-East Turkey
}

\author{
*Gökhan ABAY ${ }^{1}$ \\ ${ }^{I}$ Department of Plant Materials and Propagation Techniques, Division of Landscape Architecture, Recep Tayyip \\ Erdogan University, Rize, Turkey;
}

\begin{abstract}
Received: 05.06.2017
Revised: 04.11.2017

Accepted: 12.10.2017

Abstract

Based on the published papers, floristic investigations of bryophytes (liverworts and hornworts) were carried out for subalpine and alpine localities in the boundary of Rize province in Turkey. The number of bryophyte taxa in these regions is 140 (119 mosses and 21 liverworts) with the lists cited in this paper. The hepatic list includes 15 genera and also mosses 55 genera. The largest genera of liverworts and mosses were found to be Scapania with four taxa and Sphagnum is with 13. Racomitrium heterostichum, R. macounii, Ditrichum pusillum, and Hymenoloma crispulum were the most common moss species. Two liverworts, Aneura pinguis and Scapania undulata were noted as the most common. When the altitudinal data were analyzed, it was seen that $2300 \mathrm{~m}$. is the most survey area of intensive collecting. Upper limits of the taxa are observed at 3060 and $3065 \mathrm{~m}$. Bryophyte records above $3000 \mathrm{~m}$ were not very rich according to the available information. The study provides an updated and useful catalog of the bryophytes occurring above forest boundary of Rize.
\end{abstract}

Keywords: Mosses, liverworts, subalpine, alpine, Rize, Turkey

\section{Introduction}

Studies on subalpine and alpine bryophytes in many regions of the world are well documented in terms of floristics, endemism, phytogeographic, and ecological considerations (Watson, 1925; Bartram, 1949; Delgadillo, 1971, 1979; Spence, 1986; Enroth, 1990; Austrheim et al., 2005; Bruun et al., 2006; Jägerbrand et al., 2006; Sabovljević, 2006; Dibble et al., 2009; Hinds et al., 2009; Miller, 2009; Ignatov et al., 2010; Puglisi et al., 2011; Ah-Peng et al., 2014; Ceschin et al., 2015).

Although the diversity of vascular plants (Güleryüz, 2000; Atay et al., 2009) and knowledge about vegetation (Vural, 1996) in subalpine and alpine regions of different parts in Turkey are well known, the diversity of bryophytes in these areas is poorly documented. All studies on the bryophytes of these regions have been done as general floral studies, some of which include species of alpine or subalpine sections. In particular, there are no bryofloristic studies directly about alpine or sub-alpine zones in
Turkey, but many papers including subalpine and alpine bryophyte species and also new record bryophyte taxa reported from the high elevations have been performed from various locations in Turkey over the last five years (Ezer and Kara, 2012; Kırmac1 et al., 2012; Özdemir et al., 2012; Batan and Özdemir, 2013; Batan et al., 2013; 2016a, 2016b, 2016c; Kırmacı and Kürschner, 2013; Kırmacı and Erdağ, 2014; Kara et al., 2014).

One of the most comprehensive bryofloristic lists about Rize was given as a checklist by Abay et al. (2016). The aim of the present study is also to provide information about bryophytes collected along subalpine and alpine areas of Rize in Turkey with their current names.

\subsection{Area Description}

The province Rize, north-east of Turkey, is surrounded by Artvin in the east, Trabzon in the west, and Erzurum in the south. It has an area of about 4000 $\mathrm{km}^{2}$. The forest boundary in the province lies at about

* Corresponding author: gokhan.abay@erdogan.edu.tr (C) 2017 All rights reserved / Tüm haklart saklidir.

To cite this article: Abay G. 2017. A preliminary list of subalpine and alpine bryophytes of Rize, North-East Turkey). Anatolian Bryology. 3(2): 75-80. 
2000 to $2400 \mathrm{~m}$. The upper part of forest line consists of subalpine and alpine meadows. The alpine area is covered with snow between the months of November and March. The highest summit of the Eastern Black Sea Mountains is within the boundaries of the province and there are 18 summits with an altitude above $3300 \mathrm{~m}$. The most important of these are Kaçkar (3932 m), Verçenik (3709 m), Altıparmak (3605 m), Kemerkaya (3562 m), Dilek (3549 m), Aksu (3434 m), Demir (3354 m), and Cimil (3344 m). There are many small glacial lakes around some of these summits (Vural, 1996).

\section{Materials and methods}

The altitudinal limits of listed bryophytes were determined considering the upper limit of forest vegetation in Vural's work, published in 1996. Accordingly, the study is based on the published 12 papers including subalpine and alpine bryophytes above $2000 \mathrm{~m}$. asl. within the boundary of Rize between the years 1955 and 2016. Besides, bryophyte distributions within subalpine and alpine areas of the province were analyzed using information collected by Henderson and Muirhead (1955), Henderson (1964), Kürschner and Parolly (2006a, 2006b), Abay et al. (2006, 2007, 2009a, 2009b), Keçeli et al. (2008), Uyar et al. (2008), Kırmaci et al. (2012), and Kırmac1 and Kürschner (2013). The current named lists were categorized alphabetically and separately. The hepatics nomenclature was updated according to Ros et al. (2007). Ros et al. (2013) and Lara et al. (2016) were also used for mosses. The synonyms of the hepatics and mosses were given at the end of the text with an appendix.

\section{Results and Discussion}

\subsection{Results}

The liverwort and moss lists report data on 140 subalpine and alpine taxa recorded from different localities above $2000 \mathrm{~m}$ asl. within the Rize province. The hepatics list includes 15 genera and 21 taxa. The largest number of liverwort species was found in the genus Scapania (4). Following is the genera, Cephalozia, Jungermannia, and Tritomaria, each having two taxa. Finally, the others were represented by one taxon. In case of mosses, they are represented by 55 genera and 119 taxa. The genus Sphagnum is the richest comprising 13 members. Grimmia (9), Racomitrium (7), Dicranum (5), Lescuraea (5), Philonotis (5), Brachythecium (4), Ditrichum (4), and Ptychostomum (4) are some other rich genera.

The liverworts and mosses listed below are from subalpine and alpine areas of Rize.

\section{ALPHABETICAL LIST OF MARCHANTIOPHYTA (Liverworts)}

Aneura pinguis (L.) Dumort.

Anthelia julacea (L.) Dumort.

Barbilophozia hatcheri (A. Evans) Loeske
Cephalozia bicuspidata (L.) Dumort.

C. pleniceps (Austin) Lindb.

Diplophyllum albicans (L.) Dumort.

Eremonotus myriocarpus (Carrington) Pearson

Jungermannia hyalina Lyell

J. obovata Nees

Marsupella funckii (F.Weber \& D.Mohr) Dumort.

Pellia endiviifolia (Dicks.) Dumort.

Porella arboris-vitae (With.) Grolle

Radula lindenbergiana Gottsche ex C. Hartm.

Reboulia hemisphaerica (L.) Raddi

Riccardia chamedryfolia (With.) Grolle

Scapania irrigua (Nees) Nees

S. paludosa (Müll. Frib.) Müll. Frib.

S. subalpina (Nees ex Lindenb.) Dumort.

S. undulata (L.) Dumort.

Tritomaria exsecta (Schmidel ex Schrad.) Loeske

T. quinquedentata (Huds.) H. Buch

\section{ALPHABETICAL LIST OF BRYOPHYTA} (Mosses)

Andreaea rupestris Hedw.

Anomodon viticulosus (Hedw.) Hook. \& Taylor

Atrichum tenellum (Röhl.) Bruch \& Schimp.

Aulacomnium palustre (Hedw.) Schwägr.

Bartramia ithyphylla Brid.

Brachytheciastrum velutinum (Hedw.) Ignatov \&

Huttunen

Brachythecium geheebii Milde

B. glareosum (Bruch ex Spruce) Schimp.

B. mildeanum (Schimp.) Schimp. ex Milde

B. rivulare Schimp.

Bryum argenteum Hedw.

B. schleicheri DC.

Ceratodon purpureus (Hedw.) Brid.

Coscinodon cribrosus (Hedw.) Spruce

Cratoneuron filicinum (Hedw.) Spruce

Dichodontium palustre (Dicks.) M. Stech

Dicranodontium denudatum (Brid.) E. Britton

Dicranoweisia cirrata (Hedw.) Lindb.

Dicranum bonjeanii De Not.

D. flexicaule Brid.

D. fuscescens $\mathrm{Sm}$.

D. polysetum $\mathrm{Sw}$. ex anon.

D. scoparium Hedw.

Didymodon luridus Hornsch.

D. vinealis (Brid.) R.H. Zander

Distichium capillaceum (Hedw.) Bruch \& Schimp.

D. inclinatum (Hedw.) Bruch \& Schimp.

Ditrichum flexicaule (Schwägr.) Hampe

D. heteromallum (Hedw.) E. Britton

D. pusillum (Hedw.) Hampe

D. subulatum Hampe

Encalypta vulgaris Hedw.

Fontinalis antipyretica Hedw.

Grimmia alpestris (F. Weber \& D. Mohr) Schleich.

G. decipiens (Schultz) Lindb.

G. elatior Bruch ex Bals.-Criv. \& De Not.

G. laevigata (Brid.) Brid.

G. longirostris Hook. 
G. montana Bruch \& Schimp.

G. ovalis (Hedw.) Lindb.

G. pulvinata (Hedw.) Sm.

G. trichophylla Grev.

Hedwigia ciliata (Hedw.) P. Beauv.

Helodium blandowii (F. Weber \& D. Mohr) Warnst.

Heterocladium dimorphum (Brid.) Schimp.

Hymenoloma crispulum (Hedw.) Ochyra

Hypnum andoi A.J.E. Sm

Isothecium alopecuroides (Lam. ex Dubois) Isov.

I. myosuroides Brid.

Lescuraea incurvata (Hedw.) E. Lawton

L. patens Lindb.

L. plicata (Schleich. ex F. Weber \& D. Mohr) Broth.

L. radicosa (Mitt.) Mönk

L. saxicola (Schimp.) Molendo

Leskea polycarpa Hedw.

Lewinskya rupestris (Schleich. ex Schwägr.) F.Lara,

Garilleti \& Goffinet

Mnium lycopodioides Schwägr.

M. marginatum (Dicks.) P. Beauv.

Palustriella commutata (Hedw.) Ochyra

$P$. decipiens (De Not.) Ochyra

$P$. falcata (Brid.) Hedenäs

Paraleucobryum enerve (Thed.) Loeske

Philonotis caespitosa Jur.

P. calcarea (Bruch \& Schimp.) Schimp.

P. fontana (Hedw.) Brid.

$P$. seriata Mitt.

P. tomentella Molendo

Pogonatum urnigerum (Hedw.) P. Beauv.

Pohlia ludwigii (Spreng. ex Schwägr.) Broth.

P. nutans (Hedw.) Lindb.

P. obtusifolia (Vill. ex Brid.) L.F. Koch

Polytrichastrum alpinum (Hedw.) G.L. Sm

Polytrichum commune Hedw.

$P$. juniperinum Hedw.

$P$. piliferum Hedw.

Pseudoleskea incurvata (Hedw.) Loeske

Pseudoleskeella nervosa (Brid.) Nyholm

Ptychostomum capillare (Hedw.) Holyoak \& N. Pedersen

P. imbricatulum (Müll. Hal.) Holyoak \& N. Pedersen

P. pallens (Sw.) J.R. Spence

P. pseudotriquetrum (Hedw.) J.R. Spence \& H.P.

Ramsay var. pseudotriquetrum

Racomitrium canescens (Hedw.) Brid.

$R$. elongatum Ehrh. ex Frisvoll

$R$. ericoides (Brid.) Brid.

$R$. heterostichum (Hedw.) Brid.

$R$. macounii Kindb. subsp. macounii

$R$. macounii subsp. alpinum (E. Lawton) Frisvoll

$R$. microcarpon (Hedw.) Brid.

Rhizomnium punctatum (Hedw.) T.J. Kop.

Rhynchostegium riparioides (Hedw.) Cardot

Rhytidiadelphus squarrosus (Hedw.) Warnst.

$R$. triquetrus (Hedw.) Warnst.

Rhytidium rugosum (Hedw.) Kindb.

Sanionia uncinata (Hedw.) Loeske
Sarmentypnum sarmentosum (Wahlenb.) Tuom. \& T.J. Kop.

Schistidium atrofuscum (Schimp.) Limpr.

S. confertum (Funck) Bruch \& Schimp.

S. flaccidum (De Not.) Ochyra

Sphagnum auriculatum Schimp.

S. capillifolium (Ehrh.) Hedw.

S. centrale C.E.O. Jensen

S. compactum Lam. \& DC.

S. fallax (H. Klinggr.) H. Klinggr.

S. girgensohnii Russow

$S$. inundatum Russow

S. magellanicum Brid.

S. platyphyllum (Lindb. ex Braithw.) Warnst.

S. squarrosum Crome

S. subsecundum Nees

S. teres (Schimp.) Ångstr.

S. warnstorfii Russow

Straminergon stramineum (Dicks. ex Brid.) Hedenäs Syntrichia norvegica F. Weber

Tortella inclinata var. densa (Lorentz \& Molendo)

Limpr.

T. tortuosa (Hedw.) Limpr.

Tortula hoppeana (Schultz) Ochyra

T. marginata (Bruch \& Schimp.) Spruce

T. subulata Hedw.

Weissia controversa Hedw.

\subsection{Discussion}

The altitudinal limits of subalpine and alpine bryophyte taxa in Rize province are most strongly concentrated at 2100, 2190, 2300, 2360, and $2650 \mathrm{~m}$, and records of the taxa below $2650 \mathrm{~m}$ are more numerous than the upper elevations. When the altitudinal data are analyzed, the highest intensity of collection area is $2300 \mathrm{~m}$. Upper limits of the taxa are observed at 3060 and $3065 \mathrm{~m}$. Pohlia obtusifolia was recorded at $3060 \mathrm{~m}$ (Kirmac1 et al., 2012), and Marsupella funckii, Distichium capillaceum, Ditrichum flexicaule, and Bartramia ithyphylla were from $3065 \mathrm{~m}$ (Abay et al., 2009b). Bryophyte records above $3000 \mathrm{~m}$ were not very intensive according to available information.

A short discussion on mountain and alpine species from different countries is provided in this study. Sabovljevic (2006) gives a knowledge of bryophytes in the region of the Western Alps (Italy and France) and here some taxa such as Cephalozia pleniceps, Andreaea rupestris, Brachythecium mildeanum, Sanionia uncinata were given in a preliminary list of Rize. A list of moss species of small local mountain area in Dagestan Republic (East Caucasus) is presented by Ignatov et al. (2010). The taxa reported here; Brachythecium rivulare, Cratoneuron filicinum, Dicranum bonjeanii, Mnium lycopodioides, $M$. marginatum, Palustriella commutata, Polytrichastrum alpinum, Polytrichum juniperinum, Pseudoleskeella nervosa, Ptychostomum capillare, Sanionia uncinata, and Tortella tortuosa were also 
found in any certain high mountainous area of Rize. The mosses Dicranum flexicaule, D. polysetum, Pseudoleskea patens, Palustriella commutata, Racomitrium canescens, Schistidium atrofuscum and Tortella tortuosa reported in the present study were also found in some upper mountain belt of central Italy, by Puglishi et al. (2011).

As a result, the liverwort and moss lists about subalpine and alpine regions of Rize may be far from completion because a lot of high mountains have not been researched in detail and there are unexplored places in these sections of the province. Several possible explanations can be suggested about why the maximum studied elevations are limited to $3065 \mathrm{~m}$ only. Maybe, the upper mountain belts of Rize are under snow or it is extremely difficult to access there during most of the year.

\section{References}

Abay G. Batan N. Özdemir T. 2016. Bryophyte checklist of Rize, north-east Turkey. Arctoa. 25: 386-392.

Abay G. Uyar G. Çetin B Keçeli T. 2007. Bucklandiella microcarpa (Hedw.) Bednareck-Ochyra \& Ochyra (Grimmiaceae, Bryopsida), new to the moss flora of Turkey and South-West Asia. Cryptogamie Bryologie. 28: 145-148.

Abay G. Uyar G. Çetin B. Keçeli T. 2006. New bryofloristic records for the square A4 (Rize, Turkey). Proceedings of IV BBC, Sofia, 2026 VI. 2006: 134-139 (publ. 2009).

Abay G. Uyar G. Keçeli T. Çetin B. 2009a. Sphagnum centrale and other remarkable bryophyte records from the Kaçkar Mountains (Northern Turkey). Cryptogamie Bryologie. 30(3): 399-407.

Abay G. Uyar G. Keçeli T. Çetin B. 2009 b. Contributions to the bryoflora of the Kaçkar Mts (NE Anatolia, Turkey). Phytologia Balcanica. 15: 317-329.

Ah-Peng, C. Flores O. Wilding N. Bardat J. Marline L. Hedderson T.A.J. Strasberg D. 2014. Functional diversity of subalpine bryophyte communities in an oceanic island (La Réunion). Arctic, Antarctic, and Alpine Research. 46 (4): 841-851.

Atay S. Güleryüz G. Orhun C. Seçmen Ö. Vural C. 2009. Türkiye'nin 120 alpin bitkisi. Dönence Basım ve Yayın Hizmetleri, İstanbul.

Austrheim G. Hassel K. Mysterud A. 2005. The Role of Life History Traits for Bryophyte Community Patterns in Two Contrasting Alpine Regions. The Bryologist. 108 (2): 259 271.

Bartram E.B. 1949. Alpine Mosses from Mexico Collected by Walter Kiener. The Bryologist. 52(1): 23-27.
Batan N. Alataş M. Özdemir T. 2013. Schistidium sordidum new to Turkey and southwest Asia. Arch. Biol. Sci. 65(4):1505-1509.

Batan N. Alataş M. Özdemir T. 2016a. Hygrohypnum ochraceum (Bryophyta), new to Turkey and Southwest Asia. Phytologia Balcanica. 22(3): 331-333.

Batan N. Jia Y. Özdemir T. Alataş M. 2016b. Brotherella and Encalypta species new to Turkey, Mediterranean and Southwest Asia. Plant Biosystems. 150(3): 436-441.

Batan N. Özdemir T. 2013. New records for the moss flora of Turkey and Southwest Asia. Nova Hedwigia. 97(3-4): 437-440.

Batan N. Özdemir T. Alataş M. 2016c. New national and regional bryophyte records, 47. 32. Sematophyllum micans (Mitt.) Braithw. Journal of Bryology. 38(2): 160-161.

Bruun H.H. Moen J. Virtanen R. Grytnes J.A. Oksanen L. Angerbjörn A. 2006. Effects of altitude and topography on species richness of vascular plants, bryophytes and lichens in alpine communities. Journal of Vegetation Science. 17: 37-46.

Ceschin S. Minciardi M.R. Spada C.D. Abati S. 2015. Bryophytes of Alpine and Apennine mountain streams: floristic features and ecological notes. Cryptogamie Bryologie. 36 (3): 267283.

Delgadillo C.M. 1971. Phytogeographic Studies on Alpine Mosses of Mexico. The Bryologist. 74 (3): 331-346.

Delgadillo C.M. 1979. Notes on Alpine Mosses of Mexico. The Bryologist. 82 (4): 629-631.

Dibble A.C. Miller N.G. Hinds J.W. Fryday A.M. 2009. Lichens and bryophytes of the alpine and subalpine zones of Katahdin, Maine, I: Overview, ecology, climate and conservation aspects. The Bryologist. 112(4): 651-672.

Enroth J. 1990. Altitudinal zonation of Bryophytes on the Huon Peninsula, Papua New Guinea. A floristic approach, with phytogeographic considerations. Tropical Bryology. 2: 61-90.

Ezer T. Kara R. 2012. New national and regional bryophyte records, 33. 15. Pseudocalliergon turgescens (T.Jensen) Loeske. Journal of Bryology. 34(4): 286.

Güleryüz G. 2000. Alpine flowers of Uludağ. Bursa Valiliği, Bursa.

Henderson D.M. 1964. Contributions to the bryophyte flora of Turkey: VI. Notes from the Royal Botanic Garden, Edinburgh. 25: 279291.

Henderson D.M. Muirhead C.W. 1955. Contribution to the bryophyte flora of Turkey. Notes from the Royal Botanic Garden, Edinburgh. 22: 2943.

Hinds J.W. Fryday A.M. Dibble A.C. 2009. Lichens and bryophytes of the alpine and subalpine 
zones on Katahdin, Maine, II: Lichens. The Bryologist. 112(4): 673-703.

Ignatov M. Fedosov V.E. Igtanova E.A. Doroshina G.YA., Zolotov, V.I. 2010. Moss flora of Gunib area in Dagestan, the eastern Caucasus. Arctoa. 19: 87-96.

Jägerbrand A.K. Lindblad K.E.M. Björk R.G. Alatalo J.M. Molau U. 2006. Bryophyte and lichen diversity under simulated environmental change compared with observed variation in unmanipulated alpine tundra. Biodiversity and Conservation. 15: 4453-4475.

Kara R. Ezer Y. Can Gözcü M. Bozdoğan Ş.G. 2014. Bryophyte flora of Erciyes Mountain in Turkey, with 6 bryophyte records from the country. Turkish Journal of Botany. 38: 763 781.

Keçeli T. Abay G. Uyar G. Çetin B. 2008. New national and regional bryophyte records, 19. Scapania paludosa (Müll. Frib.) Müll. Frib. Journal of Bryology. 15: 234.

Kırmacı M. Erdağ A. 2014. Acaulon fontiquerianum (Pottiaceae), A new species to the bryophyte flora of Turkey and SW Asia. Polish Botanical Journal. 59(2): 229-233.

Kırmacı M. Kürschner H. 2013. The genus Sphagnum L. İn Turkey with $S$. contortum, $S$. fallax, S. magellanicum and S. rubellum, new to Turkey and Southwest Asia. Nova Hedwigia. 96 (3-4): 383-397.

Kırmacı M. Kürschner H. Erdağ A. 2012. New and noteworthy records to the bryophyte flora of Turkey and Southwest Asia. Cryptogamie Bryologie. 33 (3): 267-270.

Kürschner H. Parolly G. 2006a. New national and regional bryophyte records, 13. 11. Warnstorfia sarmentosa (Wahlenb.) Hedenäs. Journal of Bryology. 28: 154.

Kürschner H. Parolly G. 2006b. New national and regional bryophyte records, 12. 9. Eremonotus myriocarpus (Carrington) Lindb. \& Kall. ex Pearson. Journal of Bryology. 28: 69.

Lara F. Garilleti R. Goffinet B. Draper I. Medina R. Vigalondo B. Mazimpaka V. 2016. Lewinskya, a New Genus to Accommodate the Phaneroporous and Monoicous Taxa of Orthotrichum (Bryophyta, Orthotrichaceae). Cryptogamie, Bryologie, 37(4):361-382.

Miller N.G. 2009. Lichens and Bryophytes of the Alpine and Subalpine Zones of Katahdin, Maine, III: Bryophytes. The Bryologist. 112(4): 704-748.

Özdemir T. Batan N. Uyar G. 2012. New national and regional bryophyte records, 31. 8. Conardia compacta (Drumm. ex Müll.Hal.) H.Rob. Journal of Bryology. 34(2): 125-126.

Puglisi M. Privitera M. Di Pietro R. 2011. New records of arctic montane and alpine mosses from Central Italy. Cryptogamie Bryologie. 32 (1): 75-81.
Ros R.M. Mazimpaka V. Abou-Salama U. Aleffi M. Blockeel T.L. Brugues M. Cros R.M. Dia M.G. Dirkse G.M. Draper I. Elsaadawi W. Erdag A. Ganeva A. Gabriel R. Gonzalezmancebo J.M. Granger C. Herrnstadt I. Hugonnot V. Khalil K. Kürschner H. Losada-Lima A. Luis L. Mifsud S. Privitera M. Puglisi M. Sabovljević M. Sergio C. Shabbara H.M. Sim-Sim M. Sotiaux A. Tacchi R. Vanderpoorten A. Werner O. 2013. Mosses of the Mediterranean, an Annotated Checklist. Cryptogamie, Bryologie. 34: 99-283.

Ros R.M. Mazimpaka V. Abou-Salama U. Aleffi M. Blockeel T.L. Brugués M. Cano M.J. Cros R.M. Dia M.G. Dirkse G.M. El Saadawi W. Erdağ A. Ganeva A. González-Mancebo J.M. Herrnstadt I. Khalil K. Kürschner $H$. Lanfranco E. Losada-Lima A. Refai M.S. Rodríguez-Nuñez S. Sabovljević M. Sérgio C. Shabbara H. Sim-Sim M. Söderström L. 2007. Hepatics and Anthocerotes of the Mediterranean, an annotated checklist. Cryptogamie Bryologie. 28 (4): 351-437.

Sabovljević M. 2006. Contribution to knowledge of the bryophyte flora of the Western Alps (Italy, France). Arch. Biol. Sci. 58 (1): 61-64.

Spence J.R. 1986. The moss flora of the alpine - high subalpine Chowder Ridge area, western North Cascades Range, Washington State, U.S.A. Can. J. Bot. 64: 146-150.

Uyar G. Abay G. Çetin B. Keçeli T. 2008. Dicranum flexicaule Brid., (Dicranaceae, Bryopsida), new to the moss flora of southwest Asia. Cryptogamie Bryologie. 29: 103-106.

Vural M. 1996. Rize'nin yüksek dağ vejetasyonu. Tr. J. of Botany. 20:83-102.

Watson W. 1925. The Bryophytes and Lichens of Arctic-Alpine Vegetation. Journal of Ecology. 13(1): 1-26.

\section{APPENDIX}

\section{ALPHABETICAL LIST OF SUBALPINE AND ALPINE LIVERWORT TAXA OF RIZE INCLUDING SYNONYMS}

Lophozia quinquedentata (Huds.) Cogn. (= Tritomaria quinquedentata (Huds.) H. Buch)

\section{ALPHABETICAL LIST OF SUBALPINE AND ALPINE MOSS TAXA OF RIZE INCLUDING SYNONYMS}

Barbula lurida (Hornsch.) Lindb.(= Didymodon luridus Hornsch.)

Bryum caespiticium Hedw. (= Ptychostomum imbricatulum (Müll. Hal.) Holyoak \&

N. Pedersen)

B. capillare Hedw. (= Ptychostomum capillare (Hedw.) Holyoak \& N. Pedersen) 
B. neodamense Itzigs. (= Ptychostomum pseudotriquetrum (Hedw.) J.R. Spence \&

H.P. Ramsay var. pseudotriquetrum)

B. pallens Sw. (= Ptychostomum pallens (Sw.) J.R. Spence)

B. schleicheri var. latifolium (Schwägr.) Schimp. (= Bryum schleicheri DC.)

Bucklandiella heterosticha (Hedw.) BednarekOchyra \& Ochyra (= Racomitrium

heterostichum (Hedw.) Brid.)

B. macounii (Kindb.) Bednarek-Ochyra \& Ochyra subsp. alpinum (E. Lawton) Bednarek-Ochyra \& Ochyra (= Racomitrium macounii subsp. alpinum (E. Lawton) Frisvoll)

B. macounii (Kindb.) Bednarek-Ochyra \& Ochyra (= Racomitrium macounii Kindb.)

B. microcarpa (Hedw.) Bednarek-Ochyra \& Ochyra (= Racomitrium microcarpon (Hedw.) Brid.)

Calliergon stramineum (Dicks. ex Brid.) Kindb. (= Straminergon stramineum (Dicks. ex

Brid.) Hedenäs)

Dicranoweisia crispula (Hedw.) Milde (= Hymenoloma crispulum (Hedw.) Ochyra)

Dicranum albicans Bruch \& Schimp. nom. illeg. incl. spec. prior. (= Paraleucobryum enerve

(Thed.) Loeske)

Drepanocladus uncinatus (Hedw.) Warnst. (= Sanionia uncinata (Hedw.) Loeske)

Grimmia campestris Burch. ex Hook. (= Grimmia laevigata (Brid.) Brid.)

G. flaccida (De Not.) Lindb. (= Schistidium flaccidum (De Not.) Ochyra)

Lescuraea mutabilis var. saxicola (Schimp.) I. Hagen (= Lescuraea saxicola (Schimp.)

Molendo)

Orthotrichum rupestre Schleich. ex Schwägr. (=Lewinskya rupestris (Schleich. ex Schwägr.) F.Lara, Garilleti \& Goffinet)

Platyhypnidium riparioides (Hedw.) Dixon. (= Rhynchostegium riparioides (Hedw.) Cardot)

Pseudoleskea atrovirens (Dicks.) B. \& S. var. brachyclados B. \& S. (= Lescuraea incurvata (Hedw.) E. Lawton)

P. patens (Lindb.) Kindb. (= Lescuraea patens Lindb.)

$P$. radicosa (Mitt.) Macoun \& Kindb. (= Lescuraea radicosa (Mitt.) Mönk)

Ptychodium plicatum (Schleich. ex F. Weber \& D. Mohr) Schimp. (= Lescuraea plicata (Schleich. ex F. Weber \& D. Mohr) Broth.)

Sphagnum contortum auct. non Schultz (= Sphagnum auriculatum Schimp.)

Tortella densa (Lorentz \& Molendo) Crundwell \& Nyholm (= Tortella inclinata var. densa

(Lorentz \& Molendo) Limpr.)

Warnstorfia sarmentosa (Wahlenb.) Hedenäs (= Sarmentypnum sarmentosum (Wahlenb.)

Tuom. \& T.J. Kop.) 